
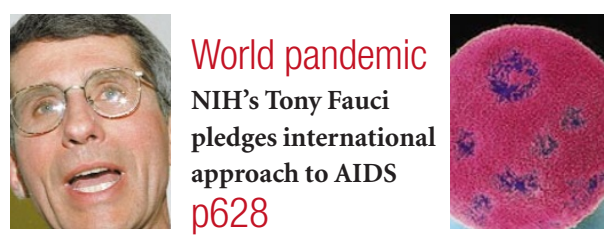

Stem cells
France moves to end
ban on human
embryo research
p629

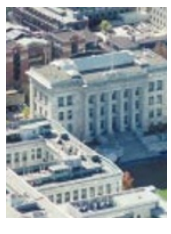

\title{
Successes in fight to save ozone layer could close holes by 2050
}

\section{Mark Schrope}

The international effort to halt ozone depletion through legislated reductions in the use of chlorofluorocarbons (CFCs) has been a success, according to leading climate researchers who met near Buenos Aires last month.

The researchers, part of the World Climate Research Programme's project on stratospheric processes, predicted that the polar ozone holes should close for good in about 50 years. But they warned that the complicating effect of greenhouse gases could lengthen the process.

The researchers say there is no direct evidence that the ozone layer is recovering. But, they add, the stabilizing of CFC concentrations in the lower atmosphere means that such a recovery is assured.

Sherwood Rowland of the University of California at Irvine, who shared the 1995 Nobel Prize for Chemistry for his part in the discovery that CFCs destroy ozone, agrees with the researchers' projections, and adds that the effects of greenhouse gases should be relatively small and short lived. "The story is approaching closure, and that's very satisfying," Rowland says.

In the upper atmosphere, or stratosphere, CFCs can spark a complex chain of chemical reactions that leads to the production of chlorine and the destruction of ozone. Researchers say that CFC concentrations will take another decade or so to level off and begin to decrease - indeed, the biggest ever ozone hole was seen over the Antarctic earlier this year. The reason for the time lag is that CFCs are inert and persist in the atmosphere for up to a century.

This delay has led to some confusion about the effectiveness of the CFC bans agreed by 170 countries in the 1987 Montreal Protocol. But Alan O'Neill, a climate modeller at the University of Reading in England and chair of the meeting's organizing committee, says that the record-breaking hole is not surprising.

O'Neill says that models of how the atmosphere should behave now match observed trends well. Assuming that current CFC policies continue, the models forecast

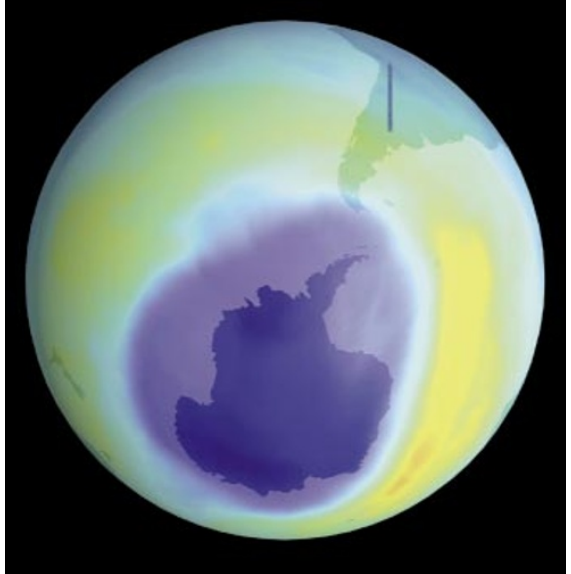

Hole story? The ozone hole looms large in this September image from the TOMS-EP satellite.

that the ozone holes that open up over Antarctica each year and over the Arctic periodically should be gone by about 2050.

But he says that higher concentrations of greenhouse gases - the effects of which have not been reliably modelled - could push that date back by a few decades.

Greenhouse gases are thought to impede ozone repair by expanding the area of the stratosphere in which ozone is destroyed. This is because the gases, although they warm the lower atmosphere, cool the stratosphere, forming ice crystals which catalyse the destruction of ozone by CFCs.

The combination of lingering CFCs and more greenhouse gases could lead to even more severe ozone holes in the short term. "Ozone could be at its lowest ever in five years time," says O’Neill, "but in the longer term we ought to be in business for recovery." Large volcanic eruptions, which launch dust into the stratosphere, could also cause short-term depletion, researchers say.

Drew Shindell, an atmospheric chemist at the NASA Goddard Institute for Space Studies in New York, says that the meeting marked a new appreciation of the confounding role of greenhouse gases in ozone depletion. Nonetheless, he says, "the agreement to limit production [of CFCs] looks like it's been an unqualified success. The science was listened to, policy-makers did something, and it actually worked."

\section{Gridlock stalls NIH budget rise}

Paul Smaglik, Washington

While the United States enters December without having elected a president, biomedical researchers face an even more pressing problem. Thanks to gridlock in Washington, the National Institutes of Health (NIH) still has no budget for the 2001 financial year, which began on 1 October.

Congress returns this week for a session that was expected to agree on the appropriations bill that funds the NIH. The bill was expected to include a massive $15 \%$ increase, taking the agency's budget to $\$ 20$ billion. But with Congress disinclined to pass a version that outgoing president Bill Clinton would sign, it is anyone's guess when the NIH will get the money.

As the first grants for the 2001 fiscal year go out this week, the uncertainty is starting

^ ๑ 2000 Macmillan Magazines Ltd to hit home, says Wendy Baldwin, the NIH's deputy director of extramural research.

"Not as many people will get money, and those that will won't get as much."

Even if the NIH gets its 15\% increase, there is no guarantee that the money will be backdated to October. If the electoral impasse leaves the NIH with a smaller increase than had been expected, it would dampen the agency's chances of doubling its budget over a five-year period - the full $15 \%$ would take the NIH halfway there.

Biomedical research lobbyists are unsure how or when the impasse will end. At worst, the government might maintain the $\mathbf{2 0 0 0}$ levels into 2001, and then decide that the agency could not manage a year's worth of budget hikes in a shortened period. 1 http://grants.nih.gov/grants/news.htm 